УДК 398.2

\title{
РЕПРЕЗЕНТАЦИЯ КУЛЬТУРНЫХ И НАЦИОНАЛЬНЫХ ОСОБЕННОСТЕЙ ПОСРЕДСТВОМ ПАРЕМИЙ В АНГЛИЙСКОМ ЯЗЫКЕ
}

\author{
Идразова Элина Сайд-Ахмадовна \\ к.ф.н. \\ ФГБОУ ВО «Чеченский \\ государственный университет»
}

\begin{abstract}
Аннотация: В данной работе рассматривается один из фольклорных жанров английского языка - паремии. Английский язык - это богатейший источник пословиц и поговорок. Они встречаются повсеместно: в разговорной речи, в газетных статьях, в литературных произведениях, в радио и телепередачах, в фильмах и мультфильмах. Рассмотрено более 2000 английских пословиц и поговорок. Их анализ позволил выделить 14 аксиом и характеристик поведения.

Ключевые слова: Английский язык, пословицы, поговорки, паремии, культурные и национальные особенности.

\section{REPRESENTATION OF CULTURAL AND NATIONAL PECULIARITIES THROUGH PAREMIAS IN ENGLISH LANGUAGE}

\section{Idrazova Elina Said-Akhmadovna}

\begin{abstract}
This work is examined one of the folklore genres of the English language - paremia. The English language is a rich source of proverbs and sayings. They are found everywhere: in colloquial speech, in newspaper articles, in literary works, in radio and TV shows, in films and cartoons. More than 2000 English proverbs and sayings were considered. Their analysis made it possible to single out 14 axioms and characteristics of behavior.

Key words: English, proverbs, sayings, paremias, cultural and national characteristics.
\end{abstract}


Известно, что главной особенностью паремий является то, что они посредством объективной оценки явлений действительности, выражают мировоззрение народа. В пословицах и поговорках отражается образ суждения народа, склад его ума, отличительные особенности воззрения. Также в них выражаются нрав, обычаи, традиции, быт, характер и т. д. По словам И. М. Снегирева ««Кажется, нигде столь резко и ярко не высказывается внешняя и внутренняя жизнь народов всеми её проявлениями, как в пословицах, в кои облекается его дух, ум и характер» [2, с. 140] многие исследователи (такие как А.Е. Супрун, А.В. Кунин, И.Р. Гальперин, Ю.А. Сорокин) определяют паремии как лингвокультурный текст, передающий культурные сведения разных народов, показывающий важнейшие исторические моменты, нрав и обычаи носителей соответствующего языка [3] .

Этими же исследователями паремии воспринимаются как лингвокультурные тексты, которые имеют в своем составе культурномаркированные лексемы и отражают в сознании представителей языка определённое видение ситуации. По мнению В.И. Карасика и О.А. Дмитриевой общность этих сведений составляет культурно-исторический фон паремий [1] Специфика мировосприятия репрезентируется в культурных и языковых характеристиках пословиц.

Особенности быта, обычаи и традиции, история и культура отражаются в лексических единицах языка, и выявляется посредством национального менталитета.

Культура народа - это проявление деятельности национального менталитета, ведь культура народа не мыслима вне менталитета его представителей. Всё это отражается в лексическом фонде языка, что доказывает частое рассмотрение данного аспекта в работах многих исследователей. Основной отличительной чертой национального менталитета являются черты характера определенного народа, этническая модель поведения, мировоззрение и миропонимание и мироощущение, которые находят свое яркое отражение в устойчивых выражениях, т. е. пословицах и поговорках.

Пословицы и поговорки - это древнейший жанр устного народного творчества любого народа. Это человеческое наследие, которое своими корнями уходит в далекое прошлое. Это доказывает то, что многие из них появились ещё до возникновения письменности. Поэтому они являются неоценимым материалом для изучения языковой картины мира любого народа. 
Английский язык - это богатейший источник пословиц и поговорок. Они встречаются повсеместн: в разговорной речи, в газетных статьях, в литературных произведениях, в радио и телепередачах, в фильмах и мультфильмах.

Нами рассмотрено более 2000 английских пословиц и поговорок. Их анализ позволил нам выделить следующие аксиомы и характеристики поведения:

1. преемственность: When in Rome do as the Romans do. В чужой монастырь со своим уставом не ходят (не ходи) [5].

2. патриотизм: East or west, home is best. There is no place like home.

На чужбине и сладкое в горчицу, а на родине и хрен за леденец [5].

3. толерантность (терпимость): So many countries, so many customs. Что город, то норов, что деревня, то обычай [5].

4. житейская мудрость, как совет поведения: Four eyes see more than two (four heads are better than two; two heads are better than one). Одна голова хорошо, а две лучше; ум хорошо, а два лучше. Better speak truth rudely than lie covertly. Лучше говорить правду в глаза, чем злословить за спиной [4]. Big head and little wit. Летами ушёл, а ума не дошёл; борода выросла, а ума не вынесла. Art is long, life is short. Век живи - век учись. Experience is the mother of wisdom. Жизненный опыт - основа мудрости. Poverty is not a shame (not a crime, no $\sin )$. Бедность - не порок [4].

5. дань и уважение традициям и обычаям Old customs are best. Bce новое - это хорошо забытое старое [6].

6. дальновидность (предусмотрительность, осторожность): Caution is the parent of safety. Осторожность - спутник безопасности; береженого бог бережет. Tattler is worse than a thief. Болтун опаснее врага. Wolf in sheep's array. Волк в овечьей шкуре [4].

7. терпеливость: Everything comes to him who waits. Кто ждёт, тот дождется Time cures all (time is the best healer; time is the nurse and breeder of all good) Время - лучший лекарь; время пройдёт - слёзы утрет. Time works wonders. Время творит чудеса [4].

8. стандарты жизни: вежливость: All doors open to courtesy. Для вежливости все двери открыты основательность, настойчивость, целеустремлённость: In every beginning think of the end. Если берешься за дело, продумай его до конца; не мудрено начать, мудрено кончить. Jack of all trades 
and is master of none. За всё браться - ничего не сделать. If you run after two hares, you will catch neither. За двумя зайцами погонишься - ни одного не поймаешь. Выделяются определенные табу: Не будь: жадным: Covetous man is a good to none but worst to himself. Жадный человек - всем враг, а себе - самый большой обманчивым: Friar, a liar. Как монах, так и лжец завистливым: Envy has no holiday зависть покоя не даст Envy shoots at others and wounds herself зависть целиться в других, а ранит себя. злым Two wrongs don't make a right. Злом зла не поправишь. [4].

9. трудолюбие: After dinner comes the reckoning. Любишь кататься люби и саночки возить. Cat in gloves catches no mice. (apples don't grow on monkey-trees; he that would eat the fruit must climb the tree; he that would have eggs, must endure the cackling of hens; he that would thrive must rise at five). Без труда не вытащишь и рыбки из пруда; любишь кататься - люби и саночки возить. By doing nothing we learn to do ill. Безделье портит человека [4].

10. смелость, отвага: Cheek brings success( fortune favours the brave) Смелость города берет; кто смел, тот два съел [4].

11. быть неприхотливым, довольствоваться малым: Bad bush is better than the open field. Лучше мало, чем ничего. Asses that bray most eat least. Кто сильно перебирает, тот мало ест. Grasp all, lose all (all covet all lose). За большим погонишься - малое потеряешь. Little is better than none ближняя соломка лучше дальнего сенца [4].

12. гордость, достоинство: Better a glorious death than a shameful life. Лучше славная смерть, чем постыдная жизнь. Bad wound is cured, not a bad name. Лучше лишиться жизни, чем доброго имени.

13. своевременность: Make hay while the sun shines. Куй железо, пока горячо.

14. честность: Fault once denied is twice committed. Кто не признаёт свою вину, тот дважды виноват. Fault (sin) confession is half forgiven. За признание половина наказания [4].

Паремии - это неотъемлемая часть народного фольклора. Они несут в себе глубокий смысл и отражают все сферы человеческой жизни. Это доказывают английские пословицы и поговорки, которые репрезентируют вековую мудрость, культуру, обычаи и традиции, быт, мировоззрение, мироощущение этого древнейшего народа. Анализ более 2000 английских пословиц и поговорок позволил выделить основные аксиомы и характеристики 
поведения: преемственность, честность, своевременность, гордость и достоинство, смелость и отвага, неприхотливость, трудолюбие, терпеливость, дань и уважение традициям и обычаям, дальновидность (предусмотрительность, осторожность), толерантность (терпимость), патриотизм. Среди них выделяются трудолюбие, терпеливость и толерантность как основополагающие бытия. Это доказывает наличие многочисленных эквивалентов паремий, отражающих эти концепты.

\section{Список литературы}

1. Дмитриева О.А. Культурно-языковые характеристики пословиц и афоризмов: Автореф. дис. ... канд. филол. наук. Волгоград, 1997. 18 с.

2. Снегирев И. М. Русские в своих пословицах: рассуждения и исследования об отечественных пословицах и поговорках. - Москва: URSS: Либроком, 2012. — VIII, 174 с.; 22 см.

3. Тарасова Н.А. Пословицы и поговорки как отражение национальных особенностей восприятия мира русскими и американцами/англичанами [Электронный ресурс] - Режим доступа: http://www.scienceforum.ru/2014/ pdf/6641.pdf

4. 1340 Английских пословиц и поговорок с русскими эквивалентами. М.: «Ибис». 1992. 128с.

5. Английские пословицы об обычаях и традициях. [Электронный pecypc] - Режим доступа: http://tonail.com

6. Proverbs, sayings and quotes. Customs and Traditions. [Электронный pecypc] - Режим доступа: https://fortee.ru/2015/06/03/proverbs-sayings-and-quotes$\%$ D1\%81ustoms-and-traditions/. 